\title{
Die triomf van 'n post-skolastieke mistiek oor skolastieke lojalisme: Gersonius versus Ruusbroec (postuum), 1399
}

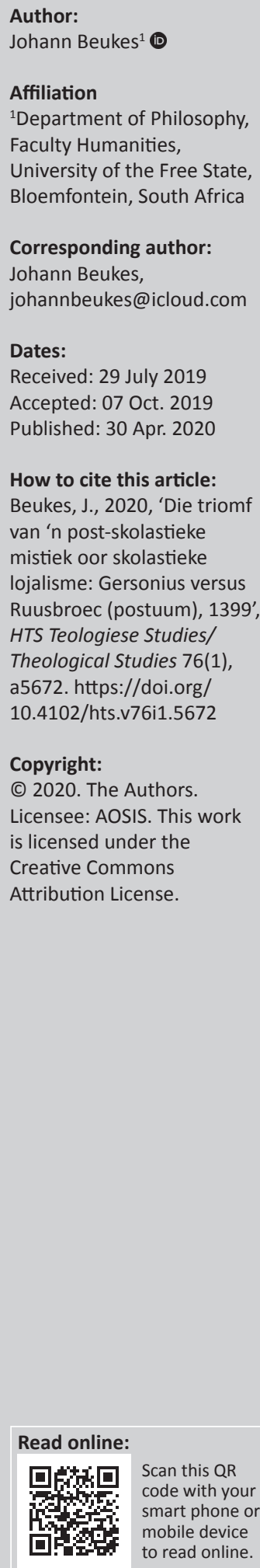

The triumph of a post-scholastic mysticism over scholastic loyalism: Gerson versus Ruusbroec (posth.), 1399. This article provides an introduction to the thought of the Flemish-Brabant 14thcentury mystical thinker, Jan van Ruusbroec, with special attention to the explosion in the niche research from 1981 (with the publication of the first volume of the Ruusbroec Opera Omnia) to 2017 (regarding the specialised outputs of the Ruusbroec Institute at the University of Antwerp). Ruusbroec is presented as a 'post-scholastic' thinker, who in an idiosyncratic way, transcended the high-scholastic aspirations of absolute clarity and certainty about God and human existence. His thought is contextualised within a polemical, posthumous context, namely the attempt of the chancellor of the University of Paris at the time, John Gerson, to get Ruusbroec's text', 'Die geestelike brulocht' declared as heresy and Ruusbroec himself as a heretic in the year 1399 AD, 18 years after Ruusbroec's death. The attempts of Ruusbroec's young colleagues at the modest monastery of Groenendaal, confronting and rearguing Gerson on this issue, are thoroughly explored. The fact that neither 'Die geestelike brulocht' nor Ruusbroec himself could eventually be effectively challenged by the high-powered Gerson, is presented as an example of the inherent potential of 'post-scholasticism' to contribute to the progression that eventually manifested itself as the 'new world', the Renaissance. No one won or lost this posthumous battle: but Gerson certainly did not win it. This is a remarkable note in, even a 'triumph' for, the archives of the small Augustinian monastery in Groenendaal, consisting of subtle 'Augustinian' monks, who had little more than a dedicated passion for Ruusbroec's mysticism (and an undergraduate in theology at the University of Paris) on their side. A hermeneutic interpretation of the events of 1399 is henceforth presented, to indicate that within the socio-political turmoil of European societies in the 14th century, there were still places (and thinkers, such as Ruusbroec), where people were able to find 'rest in God' - as there should be today.

Keywords: Boecsken der verclaringhe; Die geestelike brulocht; Jan van Ruusbroec; John Gerson; Groenendaal; Medieval mystical theology; post-scholasticism; Ruusbroec Institute Antwerp. als gode niet en willen wiken

die erdsche creaturen

so doet hi sine abolghe striken

beide ten armen ende ten riken

dit valt noch tselker uren

(Anonieme gedig uit Brabant, 1299¹)

\section{Jan van Ruusbroec: 'n Vlaams-Nederlandse mistikus uit die onstabiele 14de eeu}

Jan van Ruusbroec (1293-1381), met die mooi sobriquet Alter Dionysius (Palazzo 2011:259), was 'n sonderlinge Vlaams-Nederlandse mistikus uit die middel- en latere deel van die 14de eeu, wie se uitset van minstens 11 belangrike werke binne twee dekades na sy afsterwe in 1381, deur die kanselier van die Universiteit van Parys, Johannes Gersonius, op aanklag van kettery in 1399 bykans oor die afgrond gebring en verongeluk is.

1.as die aardse skepsel......................

om die Heer se gebooie te gehoorsaam nie

sal die Heer se wraak hulle tref

n woede teen arm en ryk tegelyk

inderdaad, dit gebeur elke dag. Per Warnar (2007:11)

Nota: Die skrywer is ook werksaam by die Sentrum vir die Geskiedenis van Filosofie en Wetenskap aan Radboud Universiteit Nijmegen, Nederland. 
Ruusbroec se integriteit as mistikus, in 'n sonderlinge periode in die Middeleeuse ideëgeskiedenis na Willem van Ockham se afsterwe in 1349 tot voor die Italiaanse Renaissance van die latere 15de eeu - die 'post-skolastiese' periode - het daardie hoog-skolastiese uitdaging egter effektief weerstaan. Tot vandag toe kan Ruusbroec se mistiek voorgehou word as 'n laat 14de-eeuse triomf van 'n 'postskolastieke mistiek' oor (op daardie stadium, uitgediende) skolastieke lojalisme. ${ }^{2}$ Ruusbroec se oorleefde mistiek sou nie net die mistieke trajekte in die Middeleeue - gevoed deur figure soos Pseudo-Dionisius, Maximus Confessor, Richard van St. Viktor, Hadewijch van Antwerpen, Hildegard von Bingen, Mechtild von Magdeburg, Marguerite Porete, die Duitse (in onderskeid met die Latyns-skolastiese) Meister Eckhart en Katharina van Siena vars en oorspronklik reflekteer nie, maar 'n versetlike nuwe spiritualiteit wat in aantog was, net meer as 'n eeu weg, aankondig: die Wes-Europese kerkhervorming van die vroeg-16de eeu (Erb 1984:155).

\section{Ruusbroec, gesitueer binne die post-skolastiese periode in Middeleeuse filosofie}

Ons sou egter nie kon vorder voordat die begrip post-skolastiek, waarop die argument in hierdie artikel telkens teruggaan, verantwoord is nie. Die begrip is uniek aan die skrywer se werk: die leser sal die begrip nêrens elders aantref nie. Post-skolastiek is naamlik 'n werksbegrip wat deur die skrywer ontwikkel moes word om 'n bepaalde leemte in Middeleeuse filosofie te ondervang, naamlik om die laaste fase van Middeleeuse filosofie verantwoordelik te dateer en intern te periodiseer, sonder om Middeleeuse filosofie in Renaissance filosofie te laat opgaan (sien ook Beukes 2012:2354). ${ }^{3}$ Die begrip neem vertrek vanuit 'n

\begin{abstract}
2.Erkenning word verleen aan die Department Filosofie en die Direktoraat vir Navorsingsontwikkeling aan die Universiteit van die Vrystaat vir die finansiering van n navorsingsbesoek aan die Belgiese universiteite van Antwerpen, Gent en KU Leuven vanaf 10 tot $21 \mathrm{Mei} 2019$, met die oog op toegespitste navorsing vir die skry van onder meer hien die Ruusbroe Instituut by die Universiteit van Antwerpen, in besonder Professore John Arblaster, Rob Faesen, Veerle Fraeters en Kees Schepers, asook die hulpvaardige personeel by die Instituut se biblioteek, word bedank vir die ongekwalifiseerde ondersteuning gebied tydens hierdie navorsingsbesoek aan Antwerpen. Daarby word Professo Danny Praet van die Department Filosofie by Gent Universiteit, sowel as Professore Russell Friedman en Jenny Pelletier van die De Wulf-Mansion Sentrum, Instituut vir Hogere Wijsbegeerte aan KU Leuven, bedank vir besondere ondersteuning en kritiese advies by die voorbereiding van hierdie werk.
\end{abstract}

3.Die skrywer en genoemde Pelletier in voetnota 2 hierbo, een van die beste Ockhamspesialiste tans op die internasionale toneel (sien onder meer Pelletier 2013 en Pelletier \& Roques 2017), het op 29 Mei 2019'n deurtastende gesprek by KU Leuven Pelletier \& Roques 2017), het op 29 Mei 2019 n deurtastende gesprek by KU Leuven gevoer, onder andere oor die skrywer se aanbod van die begrip post-skolastiek. Pelletier het tydens die gesprek voorbehoude geopper oor hierdie begrip en gevr dat alternatiewe begrippe verken word. Nadat ons die saak oorweeg het, was Pelletier se voorstel uiteindelik om 'n minder gelade begrip soos die post-Ockham periode te gebruik. Die skrywer se teenkanting op hierdie voorstel was dat ' $n$ verwysing na Ockham, soveel agting as wat die skrywer vir hierdie minimalistiese Franciskaan het, daarmee weer gebruik sou word om ' $n$ werk in Middeleeuse filosofie af te sluit, wat binne die konteks van ' $n$ 21ste-eeuse inleidingswerk to Middeleuse filosofie as tradisionalisties, sowel as onbillik beskou sou kon word teenoor die 37 denkers wat die skrywer in ' $n$ resente inleidingswerk tot Middeleeuse filosofie (Beukes 2020a) geïsoleer het, vanuit die periode 1349 en 1464; denkers wat juis tussen Ockham en Kusa - wérklik die laaste Middeleeuse filosoof - staan. Pelletier se opvolgende teenwerping was dat die skrywer se argument behels dat post-skolastiek oorwegend nie langer 'skolasties' is nie en dat ' $n$ begrip dus gebruik post-skolastiek oorwegend nit ' langer 'skolasties' is nie en dat 'n begrip dus gebruik word, al is dit uitdruklik in ' $\mathrm{post}$ geneem wil word, wat die aanbod en gebruik van die begrip in hierdie sin dan as selfondermynend kwalifiseer. Daarop was die skrywer se reaksie dat die 37 denkers wat binne hierdeperiod gekenmerk kan word nie, maar dat hulle almal steeds diep afhanklik van die skolastiese metode was en ook nie sonder hulle skolastiese agtergronde verstaan sou kon word nie. Die skrywer verantwoord die skepping en handhawing van die eenvoudige ensiklopediese vraag, naamlik: Wat het in Middeleeuse filosofie gebeur tussen die afsterwes van Willem van Ockham (1349) en Nikolaus van Kusa (1464), en waarom is hierdie periode van 115 jaar so dwingend onderbepaald in die Westerse ideëgeskiedenis? Dit is die periode in die laaste fase van laat-Middeleeuse filosofie, waar die via moderna en logica modernorum reeds duidelik afstand geneem het van die fundamentele premisses van die hoog-skolastiek, oor meer as 'n duisend jaar vanaf die via antiqua et logica vetus van Augustinus en Boethius na Petrus Abelardus, Thomas Aquinas en Johannes Duns Skotus, na die via moderna et logica nova, soos by uitstek gemanifesteer in die kenteorie van die latere Ockham, en betreklik gelyklopend, in die politieke teorie van Marsilius van Padua.

Die aanbod van hierdie idiosinkratiese begrip kom op ' $n$ transformasie van die hoog-skolastiek op grond van 'n selektiewe afskeid van bepaalde aspekte van die hoog-skolastiek neer. Hierdie selektiewe afskeid vind die skrywer in 'postskolastiese temas', onder andere in die politiek-teoretiese intensifisering van die via moderna (Padua), die finale skeiding tussen teologie en filosofie en die gevolglike verselfstandiging van die natuurwetenskappe (Bradwardine), in res institusiekritiek (Wyclif), transformerende pragmatiek (Biel), materialisme (Blasius van Parma) en Kusa se dialektiesspekulatiewe mistiek. ' $n$ Tendens in by verre die meerderheid moderne inleidingswerke tot en bloemlesings in Middeleeuse filosofie, naamlik om reguit vanaf Ockham na Kusa te beweeg, laasgenoemde dikwels getipeer as 'tegelyk die laaste Middeleeuse en eerste Renaissance filosoof', is oorhaastig in die verbygaan van meer as 'n eeu se intellektuele geskiedenis, wat deur die begrip post-skolastiek verteenwoordig word. Hierdie verbygaan word enersyds gestu deur ' $n$ voordatering van Renaissance filosofie, in 'n poging om sowel die gaping tussen Ockham en Kusa sover moontlik te verklein, en andersyds om die selfstandigheid van hierdie periode tussen die hoog-skolastiek en Renaissance filosofie, te onderspeel. Andersyds word die betrokke periode met 'n skerp verbygaan van die idiosinkratiese momente daarin teenwoordig, met reëlmaat as 'intellektueel dor' en 'filosofies steriel', synde die 'tyd van die leerling' teenoor die vorige (in die vroeg- en hoog-skolastiese periodes) twee eeue as die 'tyd van die leermeester', opgestel.

'Post-skolastiek' (van hier af sonder aanhalingstekens) vervul juis 'n belangrike swaelstertfunksie in die sistematiese, hoewel talmende oorbeweeg vanaf hoog-skolastiek na Renaissance- en vroeg-moderne filosofie. Ons het hier dus nie te make met abrupte afskeide van die skolastiese periodes nie, maar met transisionele oorgange wat gedra is deur oorgangsdiskoerse - soos juis post-skolastiek. Die moderne weergawe van Middeleeuse filosofie gaan grootliks by die delikaatheid van hierdie afskeid van die Middeleeue verby, in haar teleologiese poging om die gewaande kairos van die

begrip graag met verwysing na hierdie intensiewe gesprek met Pelletier, omdat die verwysing na 'skolasties' in die begrip post-skolasties, juis nog die latente, nawerkende skolastiese moment eerbiedig. 
moderne gebeure te verwelkom. Post-skolastiek was nie, om die moderne jargon te gebruik, net nóg 'n skadukol in die 'altyd donker tyd' waarby verbygegaan sou moes word in die kenmerkend haastige sprong vanaf Ockham na Kusa nie. Post-skolastiek is dus ook nie bloot die laaste asem van die skolastiek nie, maar op grond van die selektiewe afskeid van hoog-skolastiek, die transformasie daarvan. Dit is juis die toenemend nie-religieuse aksente in post-skolastiese sekularisme, institusiekritiek, materialisme en inderdaad die aardse soort mistiek wat ons by Ruusbroec teëkom, wat dit van sowel hoog-skolastiek as Renaissance filosofie onderskei.

Terug by Ruusbroec as sodanig: ${ }^{4}$ hierdie sonderlinge denker het hom binne onmoontlike omstandighede in ' $n$ absoluut chaotiese Wes-Europese konteks in die tweede helfte van die 14de eeu bevind. Wes-Europa was in anargie gedompel, inderdaad omdat 'die Middeleeue ' $n$ afloop begin toon het en 'n nuwe era koorsagtig begin aanbreek het' (Mommaers 1981:17). Die laaste dekades van die 14de eeu sou selfs nog skerper as 'revolusionêr' (Mommaers 1981:17) gekenmerk kon word: Politieke opstande was algemeen (onder andere die kleinboere-opstand in Vlaandere in die vroeë 1330's) en die jongnasie state - nou bevry van die knellende historiese en outoritêre greep van die pousdom - was uiteindelik bevry tot 'n onafhanklike, selfgenoegsame identiteitskepping.

Maar saam met vryheid kom natuurlik dikwels die versoeking om die parameters van daardie vryheid te toets en die kontoere daarvan oop te buig: Oorloë tussen hierdie jong state was algemeen en uitgerek, selfs tot so lank as 'n eeu. Gildes en gemeentes (oftewel stadsrade) het sigself teen die gesag van hertogdomme georganiseer en opgestel. Die Swart Pes het daarby vanaf 1346 tot 1369 oor die kontinent geswiep en die lewens van soveel as 50 miljoen mense geëis. Die eens magtige heilige, algemene Christelike kerk is tot in haar fondamente geskud deur die Westerse Verdeling (ook die 'Groot Schisme' genoem) van 1378 tot 1417 , wat die pousdom en die kerk self effektief geskeur het, met soveel as drie pouse wat mekaar in 1410 oor en weer geëkskommunikeer het.

Binne hierdie chaos in die tweede helfte van die 14de eeu herleef bovermelde Middeleeuse mistieke trajekte, vanaf Dionisius tot by Marguerite, maar toenemend aweregs: Allerlei vreemde bewegings wat skuilgaan onder die

\footnotetext{
4.Opvallend ontbreek inskrywings oor Ruusbroec in elke Engelse inleidingswerk waarop die skrywer die afgelope drie dekades die hand kon lê: Selfs nie die hoogs waarop die skrywer die afgelope drie dekades die hand kon lê: Selfs nie die hoogs
inklusiewe redaksiewerk van Gracia en Noone (2006) en die omvangryke inklusiewe redaksiewerk van Gracia en Noone (2006) en die omvangryke
ensiklopedie van Lagerlund (2011), bevat enige inskrywing oor of selfs ' $n$ verwysing ensiklopedie van Lagerlund (2011), bevat enige inskrywing oor of selfs ' $n$ verwysing
na Ruusbroec nie (met inbegrip van Palazzo in Lagerlund [2011:259] se terloopse opmerking). Dit verraai ' $n$ diepe vooroordeel en suspisie in die vaknavorsing jeens die mistieke denkers in Middeleeuse filosofie, wat in terme van ' $n$ algeheel modernkritiese stemming in die 21ste eeu, krities teen rigiede uitsluitingsmeganismes opgestel behoort te wees, en wat die kritiese leser daarom as onvanpas opval. Afgesien daarvan dat die skrywer se inleidingswerk (Beukes 2020a) grondige aandag aan die Arabiese en Joodse Neoplatoniste, asook die enigste ses vroulike Middeleeuse filosowe wat ' $n$ grondige teksspoor in die periode 410-1464 nagelaat het, skenk - wil hierdie inleidingswerk juis as ' $n$ hermeneuties-oop en ontvanklike, het, skenk - wil hie totaal insluitende 21ste-eeuse inleidingswerk, uitdruklik ook die mistieke denkers insluit. Dit geld uiteraard vir mistieke denkers soos Pseudo-Dionisius en Maximus Confessor vanuit die vroeë Middeleeue, maar dan ook denkers vanuit die latere skolastiese periodes, onder andere Richard van St. Viktor, Hadewijch van Antwerpen, Hildegard von Bingen, Mechtild von Magdeburg, Marguerite Porete, die Duitse (saamgelees met die Latyns-skolastiese) Meister Eckhart, Katharina van Siena en dan juis ook Jan van Ruusbroec self.
}

dowwe en onpresiese noemer mistiek tree na vore, van openbare selfflagellantes tot (sommige) vrysinnige bedelordes, wat die draagwydte van enige redelike opvatting van die vrye menslike wil met promiskuïteit en uittartende dionisiese eksesse uitgedaag het. Die Lae Lande was van hierdie wilde ontwikkelinge nie gespaar nie: Trouens, in die Hertogdom Brabant en in Vlaandere in die noorde van eietydse België, met Gent as sentrum, het talle van hierdie pseudomistieke bewegings gedy in die tweede helfte van die 14de eeu. Jan van Ruusbroec, die vader van die Nederlandse mistiek, kom juis uit hierdie spanningsvolle wêreld, gebore in die dorpie Ruisbroek, net suid van Brussel.

Vandat hy as seun op die ouderdom van 11 in Latyn en die algemene lettere opgevoed is, was dit duidelik dat Ruusbroec beskore was vir iets buitengewoon: naamlik dat hy, hoewel hy die konvensionele filosofiese en teologiese opleiding ontvang het wat hom in staat sou stel om as priester georden te word, hom nie in die (kwynende) hoog-skolastiese konteks wou begewe nie, maar as 'mistikus'- bedoelende iemand wat sy of haar kennis deur 'direkte Goddelike inwerking' ontvang het - nie in Latyn nie, maar uitdruklik in die vernakulêr of volkstaal van sy mense wou preek, leef en werk. Hy was dus uit vrye keuse nie 'n skolastikus nie, maar na sy ordening in 1317 wel aanvanklik 'n eenvoudige priester, wat eweneens uit vrye keuse vir meer as twee dekades sou werk as pastor loci van die St. Gudule Kapel in Brussel. In hierdie gestroopte konteks te St. Gudule skryf hy die eerste uitgawes van sy 11 invloedryke werke, sy omvangryke korrespondensie nie daarby ingereken nie (Warnar 2007:80-95).

\section{Ruusbroec se belangrikste werke, oopgedek in die mees onlange nisnavorsing}

In die 1970's word in die Ruusbroec-navorsing ${ }^{5 ‘} n$ merkwaardige inisiatief van stapel gestuur: die Ruusbroec Genootschap, soos wat dit aanvanklik bekend was (vandag die Ruusbroec Instituut) aan die Universiteit van Antwerpen, in samewerking met enkele Middeleeuse navorsers aan die Instituut vir Hogere Wijsbegeerte by KU Leuven, onderneem naamlik die massiewe taak om die volle Ruusbroec-korpus te herredigeer en in Engels te vertaal. In 1981 verskyn die eerste volume van die Ruusbroec Opera Omnia, met die Boecsken der verclaringhe [Klein boekie van verhelderinge] as inleidingsteks.

\footnotetext{
5. Hierdie lesing van Ruusbroec is georiënteer aan die primêre tekste (1981a, $1981 \mathrm{~b}$ $1988,2000,2001,2002,2003,2006)$, asook in besonder die volgende sekondêre tekste: Ampe (1975:45-261); Arblaster en Faesen (eds. 2014:47-80); Burger (1993:31-45); Colledge en Marler (1984:14-47); Cornet (2017:137-151); De Baere (1984:176-186, 2014:81-99); Erb (1984:153-175); Faesen (2017:59-72); McGinn (2014:130-178); Mommaers (1981:17-41, 55-80, 2009, in geheel); Noë (2014: 100-129); Petry (2006:285-291); Rolfson (1984:187-195); Schepers (2014: 237-285, 2017:152-166): Schweitzer (1984:48-67): Vekeman (1984:124-141); Verdeyen (1984:1-13). Warnar (2007, in geheel -'n uitstaande monografie) Wiseman (1984:86-99); Wie (2007, in geheel 'n uitstaande monografie) en Wiseman (1984:86-9). Die aard van hierdie artikel is ensyds oorsigtelik, in die sin dat grondig aandag gegee word aan die relevante intellektuele geskiedenis. Die artikel is andersyds analities en sinteties, bedoelende dat die primêre tekste selfstandig gelees word sonder sekondere teksbegeleiding, waarna die sekondêre tekste geraadpleeg en getoets word aan die skrywer se lesing, om tot ' $n$ koherente sintese te kom.
} 


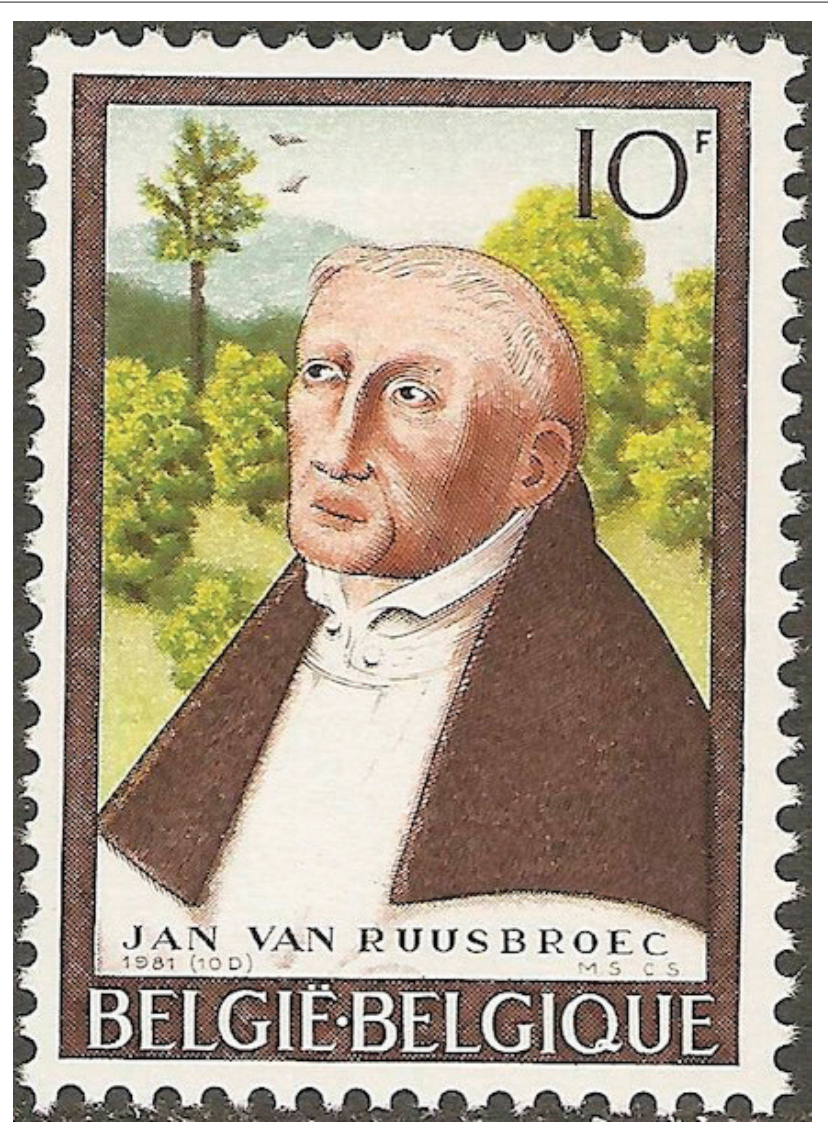

Bron: Colnect, n.d. Jan van Ruusbroec, viewed n.d., from https://colnect.com/en/stamps/ stamp/67114-Jan_van_Ruusbroec-Belgium

FIGUUR 1: 10-Frank Belgiese posseël, 1981, Seëlkatalogus BE-2028. Publieke domein.

Oor die volgende 25 jaar sou die res van die korpus volg (sien Ruusbroec 1981b, 1988, 2000, 2001, 2002, 2003 en 2006), ${ }^{6}$ met redakteurs van die kaliber van G. de Baere, P. Mommaers, J. Alaerts, M.M. Kors en R. Faesen, ondersteun deur die keurige Engelse vertalings van by uitstek $\mathrm{H}$. Rolfson (en in een werk, A. Lefevere), gebaseer op die Latynse vertalings van L. Surius vanaf 1552 en die Middelnederlandse tekste van Ruusbroec self, om die projek daarmee uiteindelik in 2006 af te handel. Die herredigeerde en hervertaalde aanbod vanuit die Ruusbroecspesialisnavorsing, by uitstek ontleen aan die institusionele ruimtes van die destydse Genootschap en huidige Instituut by Antwerpen en die Instituut by KU Leuven, is ' $n$ verbysterende prestasie. In die jaar van die verskyning van die eerste volume van Opera Omnia, is 'n 10-frank posseël met seëlkatalogus-nommer BE-2028, gepas in België bekendgestel.

Indien daarby gevoeg word die navorsingsondersteuning vanuit Nederland self, met puik redaksiewerke wat oor

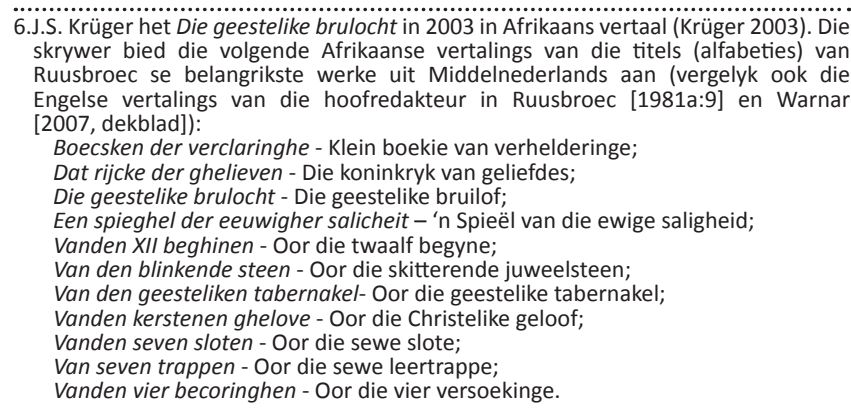

Ruusbroec in hierdie periode verskyn (waarvan Bos \& Warnar [1993] tel onder die mees uitnemende voortbordurings op die ouer magistrale werke in Frans, soos dié van Combes [1945-1972], asook die ietwat ouer Ruusbroec-monografieë in Nederlands, waaronder Ampe [1975] en juis heel resente monografieë soos dié van Warnar [2007], wat werklik buitengewoon bo peil is), word die prestige wat aan hierdie ontwikkelinge in die Ruusbroec-navorsing sedert 1981 gekoppel behoort te word, verdiep en verskerp. Daarby het die frontnavorsers by KU Leuven reeds in 1984 ' $n$ keurige redaksiewerk oor Ruusbroec in die nagloed van die sukses van die eerste volume van Opera Omnia (vergelyk De Baere 1984:176 ev), die lig laat sien, onder leiding van P. Mommaers en N. de Paepe (1984).

Met ander woorde: in slegs 25 jaar is ' $n$ denker wat tot op daardie stadium oorwegend slegs in die Lae Lande bekend was (en tot vandag toe selde of ooit in Engelse en ander nieNederlandse inleidingswerke tot Middeleeuse filosofie van 'n stem verleen word) van 'n platform van primêre en sekondêre tekste voorsien, wat hom toeganklik en as 'n aangrypende laat-Middeleeuse mistikus stel.

Tog het die Ruusbroec-spesialisnavorsing nóg 'n tree vorentoe gegee, na afhandeling van die laaste volume van die Opera Omnia in 2006: afgesien van die bewese redaksionele vermoëns van Rob Faesen met betrekking tot die redigering van Opera Omnia 9 (Van seven trappen) in 2003, beskik die Ruusbroec Instituut in Antwerpen die afgelope dekade ook oor die dienste van ander buitengewoon bekwame navorsers, onder andere John Arblaster, Veerle Fraeters en Kees Schepers. Onder die redaksieleiding van Arblaster en juis Faesen word in 2014, in die uitstekende 21ste-eeuse reeks handleidings vanuit Leiden, Brill's Companions to the Christian tradition, onder hoofredaksie van C.M. Bellito, wat spesialiseer in die publikasie en bywerking van Middeleeuse denkers in die Christelik Latynse Weste wat buite die betrokke spesialisnavorsing ondergekommentarieerd is, 'n inleidingswerk oor Ruusbroec bekendgestel (Arblaster \& Faesen eds. 2014). In hierdie werk word nie net Arblaster en Faesen (eds. 2014) self en Schepers (2014) grondig geleentheid gebied om Ruusbroec buite die nisnavorsing bekend te stel nie: ook die hoogs gerespekteerde Middeleeuse frontnavorser en Eckhart-spesialis vanuit Chicago, Bernard McGinn (2014), lewer 'n hoogstaande bydrae in hierdie aangrypende werk uit die bekwame uitgewershand van Brill te Leiden.

Arblaster en Faesen, met die momentum van die sukses van hierdie redaksiewerk in 2014 by Brill, publiseer in 2017 'n ewe deurtastende redaksiewerk, Mystical anthropology: Authors from the Low Countries, waaraan die eietydse genote van die Ruusbroec Genootschap weer met entoesiasme meegewerk het, met nogeens kwaliteit bydraes deur Cornet (2017), Schepers (2017), Van Faesen (2017) en talle ander, en Arblaster wat die verantwoordelikheid opneem om Faesen se buitengewoon tegniese bydrae, met finesse in Engels te vertaal. 
Dit is die huidige stand van die Ruusbroec-spesialisnavorsing en die situasie by die Ruusbroec Instituut te Antwerpen: wakker en produktief, met die enkele oogmerk om Ruusbroec buite die nisnavorsing in die oog te bring en met onverdrote ywer daar te hou.

\section{'n Mistiek met apologeties- kategetiese-, dogmatiese- en pastoraal-biografiese motiewe, geskryf te St. Gudule, tot 1343}

By die St. Gudule gemeente in Brussel skryf Ruusbroec as gemeentelike priester of 'kapelaan' sy eerste werke: Dat rijcke der ghelieven [Die koninkryk van geliefdes], Die geestelike brulocht [Die geestelike bruilof], Van den blinkende steen [Oor die skitterende juweelsteen], Vanden kerstenen ghelove [Oor die Christelike geloof] asook 'n gedeelte van die meer polemiese Van den geesteliken tabernakel [Oor die geestelike tabernakel]. Sy bekwame inleier tot die eerste volume van Opera Omnia, P. Mommaers (1981:18; vergelyk ook Colledge \& Marler 1984:15, asook Warnar 2007:24-49), vra ten opsigte van hierdie vroeë fase in Ruusbroec se ontwikkeling, 'n eenvoudige maar belangrike vraag: Wat het Ruusbroec as priester hoegenaamd beweeg om mistieke literatuur te begin skryf?

Mommaers (1981:18-19) antwoord dan driedelig: Eerstens het die toenemende gewildheid van bepaalde aweregse begyne groepe 'n soort apologetiese standpuntinname afgedwing. Hierdie groepe, anders as die ouer, outentieke en goed- georganiseerde bedelordes ${ }^{7}$ waarvan Mechtild von Magdeburg (Beukes 2019b; sien Beukes 2019a vir Hildegard von Bingen se unieke posisie) byvoorbeeld deel uitgemaak het, was informeel georganiseerde en lukraak gegroepeerde kwasi-mistici, wat nie 'n sistematiese (dit is, ' $n$ kritiesgeoriënteerde) mistiek beoefen het nie, maar wat bloot ' $n$ aura van mistiek uitgestraal het, om daarmee veld te wen vir wat wesenlik 'n libertynse leefwyse was (Warnar 2007:67-79). Marguerite Porete (Beukes 2020b) wat op 01 Junie 1310 op die brandstapel in Parys tereggestel is, val weliswaar meer in

7.Die woord bedel is in Afrikaans betreklik pejoratief en skakel maklik met opvattinge wat boemelary en luiheid impliseer. Allermins is dit wat die bedelordes was: Die begyne was godsdienstige groepe in die Middeleeue wat hulleself streng geslagtelik en grotendeels in terme van die gevestigde kloosterstrukture georganiseer het, sonder dat enige lid van die betrokke orde bindende geloftes moes aflê ten opsigte van ' $n$ lewe in selibaat en om gestroop te word van bestaande of toekomstige individuele eiendom (wat juis die bron van inkomste van die meerderheid van kerklik-gesanksioneerde ordes was; Eckenstein 2010:328-353). Beerderheid van kerkike en bedelnonn bedelorde enige eenmaal verlaat is nie (Lewis 1989.24). Tegnies het die begyne dus nie gebedel nie, maar was vir die daaglikse onderhoud afhanklik van die betrokke gemeenskap se barmhartigheid, waarin hulle hulle bevind het. In ruil het hulle in die gemeenskap versorgingswerk gedoen, wat ingesluit het die versorging van siekes, gebreklikes, bejaardes en weeskinders. Trouens, teen die helfte van die $13 \mathrm{de}$ eeu was die meerderheid verpleegsters in Duitsland bedelnonne. Bedelnonne was egter sosiaal blootgestel: juis omdat die bedelorde nie onder die toesig van die plaaslike klooste en provinsiale biskop gefunksioneer het nie, kon hulle nie op die soort beskerming aanspraak maak wat geordende nonne en monnike binne die kloosters en abdye geniet het nie. Juis hulle vrygeestigheid het hulle ook oopgestel vir voortdurende aanklagte van kettery (veral ten opsigte van wat beskou is as ' $n$ antroposentriese teologie en ' $n$ humanistiese mensbeskouing), seksuele immoraliteit (wat sporadies plasgevind binne selfde plaasgevind binte bederdes allermin algemeen was) en openbare bedelary (wat wel voorgekom het, maar slegs wannee die plaaslike gemeenskap die betrokke begyne versaak het; McDonnell 1954:45). I 1311 is die beweging van bedelordes by die konsilie van Vienne onder leiding van pous Clemens (pous vanaf 1305-1314) finaal veroordeel (dieselfde konsilie het pouslike ondersteuning van die gevierde Ridders van die Tempelorde teruggetrek en die bedelordes is daarna verban (Bynum 1984:175). hierdie kraal (Colledge \& Marler 1984:39-47) as in die ouer en meer stabiele begynekontekste.

Ruusbroec beskryf hierdie laaste groepering pertinent in terme van die panteïstiese moment daarin aanwesig: Wie ook al die 'vrye gees' volg wat deur hierdie groepe as die impetus vir hulle 'werksaamhede' aangebied word, word synde self 'Freien Geister' (Schweitzer 1984:50) identies met God geag, kan ineens die praktisering van die deugde aflê en hoef geen kerklike of selfs maatskaplike verantwoordelikheid of betrokkenheid verder te aanvaar nie (Schweitzer 1984:51). Ruusbroec was bekommerd oor die effek wat hierdie vrygeestige morele relativisme op die kerk sou hê, veral omdat hy daarvan oortuig was dat die kerk sélf nie langer in staat was om haarself te bewapen teen aweregse en inderdaad ketterse leerstellinge nie - die kerk was eenvoudig nie meer kategeties genoeg nie, maar veral, daar was van 'n outentieke, persoonlike religieuse ervaring, nie meer sprake in die kerk nie. Daarom is die laat-14de eeu nie net staatkundig en sosio-ekonomies in wanorde nie - die kerk is volgens Ruusbroec sélf in wanorde, die lidmate van die kerk gevolglik verstrooi en verstrooid. Daarom is hierdiekategeties-apologetiese motief teen bepaalde aweregse en provokatiewe begynegroeperinge se optrede, die eerste oorweging wat Ruusbroec daartoe bring om mistieke literatuur te begin skryf.

Tweedens beskou Ruusbroec sy mistiek as 'n dogmatiese uitset wat geestelike armoede wil aanveg, met ander woorde, sy mistiek moet die kerk en die vooruitgang van die kerk dien (Burger 1993:32). Mommaers (1981:19) dui aan dat Ruusbroec van meet af aan geredelik toegegee het dat sy mistiek gebaseer is op Katolieke dogma en dat hy die kerklike gesagstrukture wou eerbiedig, hoewel hy lugtig was vir enige vorm van hiërargie, wat sy gewildheid en nawerking in die vroeë Duitse Protestantisme verklaar (Erb 1984:155). Sy eerbiediging van die kerklike gesag hou egter nié vir Ruusbroec in dat sy innerlike religieuse ervaring daarmee gebind of onderdruk word nie. Dit hou ook nie in dat hy nie in staat is om die kerklike gesagstrukture wel institusiekrities aan te spreek nie, wat ' $\mathrm{n}$ prominente tema in beide die Die geestelike brulocht (Wiseman 1984:87) en (nog skerper by) Van den geesteliken tabernakel die geval is (Mommaers 1981:20). In laasgenoemde werk spaar Ruusbroec nie die roede nie: Hy kritiseer die kerk ferm en reguit vir die oordrewe praal en sier wat die liggaamlike instandhouding van senior kerklui kenmerk, sowel as die korrupsie wat vaardig was in die interaksie tussen vermoënde lidmate van die kerk en sodanige senior ampsdraers - en hy vertoon inderdaad nogal 'n penchant om biskoppe en abde hiervoor uit te sonder (Mommaers 1981:20).

Ruusbroec volstaan egter nie met ' $n$ kritiese aanklag teen die kerk nie: hy diagnoseer (steeds in kritiese solidariteit met die kerk) die probleem van die algehele agteruitgang van die kerk (tot dít waarheen die Westerse Verdeling enkele dekades later en drie jaar voor sy afsterwe sou lei), as sou dit te make hê met geestelike armoede. Hy vra indringend na die gebrek en afwesigheid van outentieke religieuse ervaring en 
'n diepgaande persoonlike spiritualiteit in die kerk, juis met nadruk dat hy nie die kerkvolk nie, maar die ampsdraers, vanaf die laagste priester tot die pous, primêr vir hierdie geestelike agteruitgang en armoede verantwoordelik hou. Juis in Van den geesteliken tabernakel keer Ruusbroec telkens terug na hierdie kwessie.

Daaris'nderdeenlaasterede, hoewelmeer onderbeklemtoond as voorgenoemde twee redes, waarom Ruusbroec sy mistiek sistematies begin boekstaaf het: Dit het toenemend gebeur dat mense wat hom om pastorale leiding en inderdaad spirituele advies gevra het, hom versoek het om die inhoud van hierdie gesprekke neer te pen (Mommaers 1981:21). Dit is presies die wyse waarop byvoorbeeld Van den blinkende steen tot stand gekom het. Daar was dus wel ook 'n pastoraal-biografiese motief vir die boekstelling van Ruusbroec se mistiek.

Ruusbroec begin dus in St. Gudule met ' $n$ sistematiese uiteensetting van sy mistiek, op grond van drie oorwegings: 'n Apologeties-kategetiese motief, ' $n$ dogmatiese motief in die aanvegting van spirituele dorheid in die kerk en 'n pastoraal-biografiese motief, met beduidende effek wat hierdie driedelig-geïnspireerde mistiek op gewone mense wat die gewone Middelnederlandse taal gepraat het, gehad het.

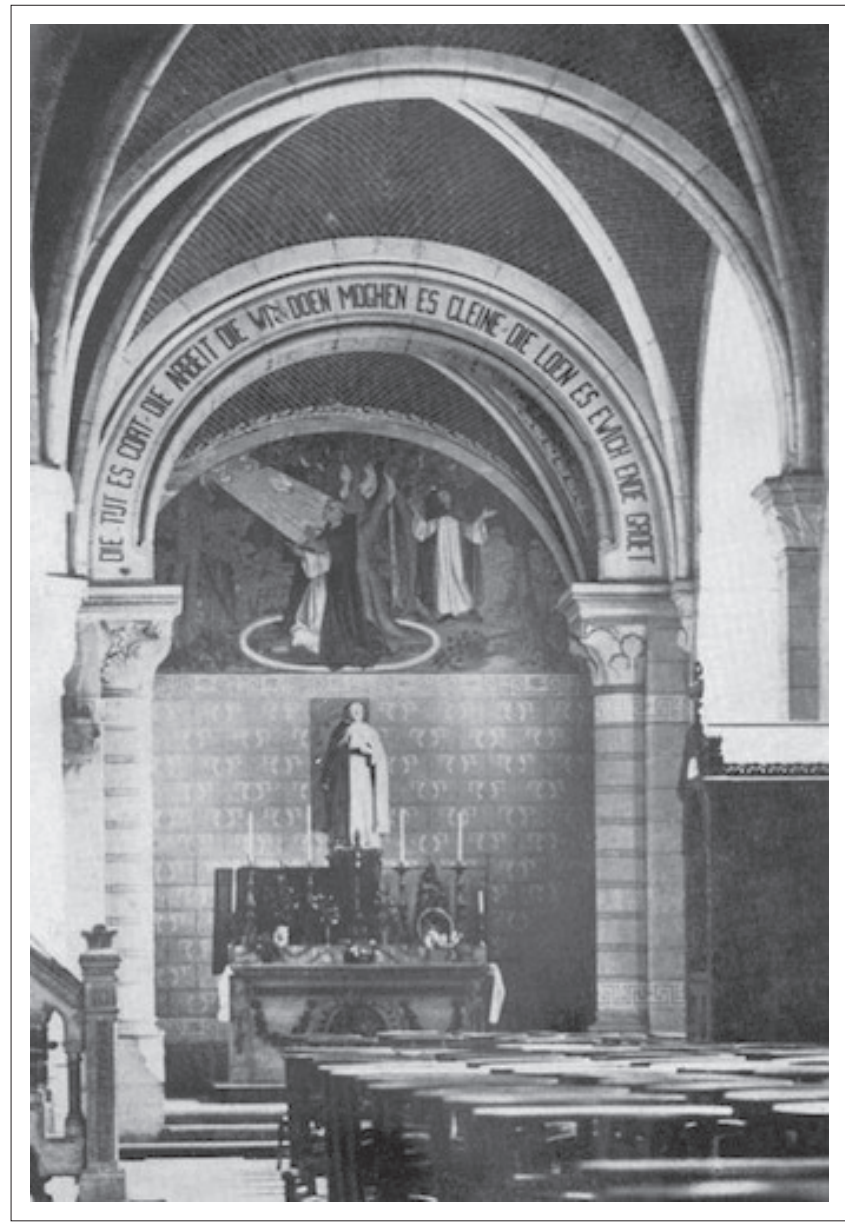

Bron: Warnar, G., 2007, Ruusbroec: Literature and mysticism in the fourteenth century, transl. D. Webb, Brill, Leiden

FIGUUR 2: Altaar gewy aan Jan van Ruusbroec, in die dorpskerkie van Ruisbroek.

\section{Die jaar 1343 en die vestiging van Groenendaal as sentrum}

In die jaar 1343 verander Ruusbroec se lewe egter onomkeerbaar. Hy besluit om 'n kontemplatiewe lewe te gaan lei in 'n beskeie huisie in Groenendaal, vroeër bewoon deur 'n hermiet, suidoos van Brussel en 'n paar kilometer die Soignes-woud in. Hy neem sy voorlopige diagnose dat die kerk se grootste ellende 'geestelike armoede' en 'n 'gebrek aan ' $n$ outentieke persoonlike spiritualiteit' is met soveel nuutopgelegde erns, dat hy hom tot hierdie stil (en mettergaande kosbare) plekkie onttrek, om minstens net eers sélf tot daardie soort spiritualiteit en 'n sin vir 'geestelike rykdom' te kan ontwikkel. In die geselskap van twee ander priesters, Jan Hinckaert en Vrank van Coudenberch, as diepe geesgenote en getroue medegangers, sou Ruusbroec die volgende vier dekades in Groenendaal deurbring.

Hierdie skuif na Groenendaal was werklik gevolgryk: Afgesien daarvan dat Ruusbroec van die kerklike hiërargie waaraan hy, synde 'n institusie-kritiese en teësinnige priester, toenemend geen erg gehad het nie, kon ontsnap, het hierdie fundamentele verandering vanaf priester na hermiet en vanaf stedeling na plattelander, hom en uiteindelik die korpus van Middeleeuse filosofie net ten goede gekom. Hy sou die restant van sy korpus hier skryf en met die hulp van Van Coudenberch in die besonder, ' $n$ klein kerkie in die woud oprig waar hy op sy eie terme en onafhanklik van die institusionele kerk, 'n mistiek-getransformeerde evangeliebeskouing kon aanbied, vir wie ook al belang daarby gehad het om die kerkie te besoek. Die kerkie is in dieselfde jaar 1343 ingehuldig, met Van Coudenberch wat as opsigter of curatus gedien het (Warnar 2007:173-226).

Mettertyd het meer stedelinge hulle tot die kerkie gewend en aansoek gerig om wel daar of daar naby in die Soignes te kon woon. Hoewel Ruusbroec ' $n$ spontane onbehae in groepvorming gehad het - veral die soort kliekvorming wat hy onder senior kerklike amptenare in die 25 jaar by St. Gudule gadegeslaan het - het hy hierdie 'nuwelinge' laat begaan, ook ter wille van Van Coudenberch, wat ' $\mathrm{n}$ diep gesosialiseerde wese was wat tussen mense gefloreer het. Gevolglik het 'n klein, 'mistieke' (bedoelende 'n diep gelowige, maar a-kerklike) geloofsgemeenskappie in Groenendaal ontstaan, wat sowel besig kon wees 'met die aardse dinge ter wille van lewensonderhoud, maar wat veral rus kon vind in God' (Burger 1993:30; sien Mommaers 1981:22).

Natuurlik sou die geïnstitusionaliseerde kerk hierdie geloofgemeenskappie nie in vrede laat nie: Op grond van die afwesigheid van ' $n$ behoorlike stel reëls oftewel 'n Ordereël waaraan hierdie 'monnike sonder 'n klooster' getoets sou kon word, tref die institusionele kerk sorg dat 'n wet uitgevaardig word wat die gemeenskap te Groenendaal en enige soortgelyke gemeenskappe 'sonder 'n Ordereël', verbode verklaar en dwing om te ontbind. Ten einde die materiële voortbestaan van die kerkie en die geestelike voortbestaan van die geloofsgemeenskap te verseker, gee 
Ruusbroec en sy medegangers toe en konformeer aan die oogmerk van hierdie wetgewing, deur uiteindelik die Ordereël van die Augustiniaanse orde oor te neem en Groenendaal effektief as 'n Augustiniaanse klooster te herorganiseer, met Van Coudenberch as dekaan en Ruusbroec as prior of hoofmonnik (Warnar 2007:187-198).

Met die jong kloostergemeenskap te Groenendaal nou sodanig gekonformeerd aan die onlangse wetgewing dat die geïnstitusionaliseerde kerk geen verdere houvas op hulle sou kon uitoefen nie, floreer Ruusbroec se tekstuele uitsette. In die 40 jaar te Groenendaal skryf Ruusbroec as 'Augustiniaanse hoofmonnik' (aanhalingstekens dus noodsaaklik) volledige en grondige filosofies-teologiese tekste, gebed in die mistieke trajekte van die Middeleeue, maar met 'n onteenseglike sin vir ' $\mathrm{n}$ konstante aanspraak op geestelike hernuwing en hervorming. Vanden vier becoringhen [Oor die vier versoekinge], Boecsken der verclaringhe [Klein boekie van verhelderinge], Vanden seven sloten [Oor die sewe slote], Een spieghel der eeuwigher salicheit [" $\mathrm{n}$ Spieël van die ewige saligheid'], Van seven trappen [Oor die sewe leertrappe] en Vanden XII beghinen [Oor die twaalf begyne] is almal in Groenendaal begin en afgehandel, terwyl Van den geesteliken tabernakel wat Ruusbroec in St. Gudule gedeeltelik klaar geskryf het, ook hier voltooi is.

Vanuit Groenendaal soek Ruusbroec gereeld kontak op met die Claris-non Margaretha van Meerbeke, van die nuut gestigte (en buitengewoon streng) klooster van Brussel, 'n medeganger wat sy geesgenoot in elke opsig was: beide Vanden seven sloten en Een spieghel der eeuwigher salicheit is (hoogs waarskynlik, Mommaers [1981:23]) aan haar opgedra, geadresseer as 'my liefste geliefde in die Here'. Ruusbroec het wel ook ander nonne-vriendinne en sekulêre vriendinne gehad (Warnar 2007:255-269). Dat Margaretha egter die een besondere invloed en teenwoordigheid in Ruusbroec se lewe was, is nie te betwyfel nie (Warnar 2007:242-249). Miskien is dit tog waar dat daar agter elke man, 'n vrou of man-vrou staan.

Maar soveel as wat Ruusbroec stilte en eenkantwees verkies het, het hy wel ook ander kosbare verhoudings gehandhaaf: Onder meer frater Gerard van die Carthusiaanse klooster in Herne, 50 kilometer vanaf Groenendaal, wat Boecsken der verclaringhe se sirkulasie bemoontlik het, het oor jare heen nougeset rekord gehou van Ruusbroec se bewegings en interesses en sodoende Ruusbroec se vroegste biograaf geword. Gerard het Ruusbroec, wat dit gehaat het om te reis, selfs sover gekry om die Carthusiaanse klooster te Herne die pad af te besoek.

Verder was dit nie ongewoon dat Ruusbroec voorgraadse en dus magister-ongebonde studente vanuit Parys ontvang het nie. Ruusbroec het ook noue kontak gehandhaaf met ' $n$ ander Gerard, met die van Groote, wat met gebruikmaking van Ruusbroeciaanse gedagtes die grondslae van die Devotio Moderna ${ }^{8}$ gelê het. Die klooster in Groenendaal het ook moeite gedoen om bestendigde verhoudings met soortgelyke klein kloosters in die Rynland, Strassburg en sover as Basel te handhaaf, asook met nie-provokatiewe begyne, teenoor 'gevaarlike begyne', soos die geheimsinnige protagonis Bloemardinne (Warnar 2007:67-79). Uit hierdie bestendigde klein-kloosterverhoudings is ' $\mathrm{n}$ substansiële deel van die laat-Middeleeuse of post-skolastiese mistiek gebore.

Ruusbroec, toe reeds 88 jaar oud, word siek in die winter van 1381 en in Groenendaal se siekeboeg opgeneem. Hy sterf na twee weke se worsteling, in die uitvaart van sy aardse liggaam en hemelse gees. Hierdie Middelnederlander sug sag en stil 'n laaste keer tussen sy broers by die klooster wat hy so liefgehad het en waar van die mees aangrypende, esoteriese mistieke literatuur uit geheel die Middeleeue geskryf is.

\section{Die (uitgediende) skolastieke lojalisme van Johannes Gersonius}

Om ' $n$ baie spesifieke hoewel negatiewe rede is ' $n$ ander denker wat in die post-skolastiese periode produktief werksaam was, belangrik: Johannes Gersonius ${ }^{9}$ (1363-1429), wie se lewenswerk getuig van ' $n$ hiperpolemiese konfrontasie met post-skolastiese denkers, ter wille van die herwinning van 'n vertroue in die outoriteit van die kerklike tradisie en die herbevordering van ' $n$ lojaliteit aan die grondslae van die hoog-skolastiek. Gersonius is belangrik, omdat sy lewenswerk daarvan getuig juis hoe futiel dit in die post-skolastiese periode geword het om sigself teen die gekombineerde impetus van Ockhamiaanse nominalisme, sekularisme, die isolering van die natuurwetenskappe, institusiekritiek, pragmatiek en materialisme te verset. Gersonius is belangrik omdat sy lewenswerk onbedoeld aandui dat post-skolastiek inderdaad terugverwys na iets wat onherroeplik verbygegaan het. Die Middeleeue, sou Gersonius uiteindelik moes aanvaar, was aan die wegkwyn. Dit was tyd vir 'n nuwe tyd.

Gersonius het op die jong ouderdom van 32 kanselier van die Universiteit van Parys geword, ' $n$ pos wat hy met skranderheid en onderskeiding beklee het vanaf 1395 tot 1418. Hy was 'n energieke mens wat bravade uitgestraal het (McGuire 2005:16; 2006:6). Gersonius was ook 'n leidinggewende figuur by die berugte konsilie van Konstans vanaf 1415 tot 1418, waar Johannes Wyclif tot ketter verklaar en Johannes Hus tereggestel is. Sy meer as twee-dekade kanselierskap van die universiteit bestryk 'n buitengewoon onrustige periode in die Franse geskiedenis, wat inderdaad 'n onrustige geskiedenis deur geheel die Middeleeue was: maar die 1400's was nog hewiger deurmekaar, 'n tyd van gewelddadige burgerlike opstande in Frankryk, veral op

gaan terug na vroulike godsdienstige beweging in die vroee. Middeleeue, maar die beweging self het eers vanaf 1375 werklik momentum gekry, vernaamlik as 'n kritiese verset teen vergrype in die kerk, veral in die pousdom self. Mistieke n kritese verset teen vergrype in die kerk, veral in die pousdom self. Mistieke inspirasie vir die Devotio Moderna gedien. 9.Sien Gersonius (1987, 1998), asook Figgis (1999:28-44,125-142); Fisher
(2006:205-248); Hobbins (2003:1308-1337, 2006:41-78); Mazour-Matusevich (2006:205-248); Hobbins (2003:1308-1337, 2006:41-78); Mazour-Matusevich Ouy (2006:79-132); South (2006:370-371) en Vial (2006:1-58). 
grond van die sosiale en ekonomiese distorsies wat geskep is deur die bitter triviale en monargies-eiesinnige Honderd Jaar Oorlog tussen Frankryk en Engeland. Die onrus is verhewig deur ' $n$ algemene vertrouensverlies aan die pouslike institusie, 'n subtiele bevraagtekening van die outonomie van die monargie en die kerklike institusiekritiek van Wyclif en Hus. Dit alles het 'n uiters negatiewe impak op die universiteitswese van die vroeg-15de eeu in Frankryk gehad, bowenal by die spoguniversiteit vir soveel eeue reeds, Parys (Pascoe 1973:14).

Gersonius, beroemd vir sy vlytige veerpen en oratoriese vermoëns, voer die oorsprong van die skade, onrus en agteruitgang in die samelewing en by die Universiteit van Parys self terug na die oorgang van die vroeg-skolastiek na die hoog-skolastiek, in terme van die werk van Johannes Duns Skotus en Willem van Ockham in die besonder. In April 1400 reik Gersonius 'n Memorandum (op daardie stadium ' $n$ interne krities-polemiese dokument, bedoel vir universiteitspersoneel alleen) uit rakende die syns insiens erbarmlike stand by die teologiese fakulteit, waarin hy dreig om as kanselier te bedank, op grond van wat hy beskryf as die 'onderrig van vruglose en inhoudlose doktrines' by die betrokke teologiese fakulteit (Luscombe 2004:170). Hy verwys in growwe polemiese taal, wat kenmerkend aan sy eindelose strydgesprekke was, in die berugte memo na die eksponente van die nominalistiesterministiese tradisie van Ockham (die nominales) as rudes [onkundiges] en na die eksponente van Skotus as curiosi et phantastici [laf en vreemd]. Beide groepe word deur Gersonius verkwalik dat hulle die onderrig van teologie met hulle 'gekekkel en stryery' gekompromiteer en 'besmeer' het (' $\mathrm{n}$ ironiese posisie, komende van iemand wat self eindeloos gestry en baklei het; ook 'n standpunt wat nogal robuust later deur Martin Luther in sy eie dikwels ondelikate en selfs onkundige geveg met die skolastici opgevolg sou word [sien Pascoe 1973:54]).

Vanaf die uitreik van daardie Memorandum sou Gersonius tot selfs na sy aftrede as kanselier beide groepe publiek bly konfronteer, nie bloot met interne 'memoranda' nie, maar met polemiese karikature wat die oorwig van sy hoogs openbare - gegewe die prominensie van sy podium - strydgesprekke sou dra. In 1402 publiseer Gersonius byvoorbeeld Contra curiositatem studentium, waarin hy die Skotiste aanval vir die invoer van metafisiese vorme, quiditeite ${ }^{10}$ en 'n 'duisend ander divisies' (Pascoe 1973:89), teenoor die hoog-skolastiese opvatting van die absolute enkelvoudigheid van God. Baie later, in 1426, publiseer Gersonius De modis significandi, waarin hy die Skotiste met detailanalises verkwalik vir die Skotiaanse afwerping van Aristoteliese logika en 'n algemene verwaarlosing van die klassieke erfenis. Die Ockhamiste weer, word bitter ironiserend getipeer as rudes et terministae

10.Quiditeit ‘n begrip regstreeks ontleen aan ibn Sina (Avicenna) en strykdeur aanwesig in die latere skolastiek, vra na die in quid van ' $n$ saak, 'wat dit is om dit te wees. Die quiditeit van 'n saak moet uitgespel word in ' $n$ standhoudende definisie van die sakk, en is soms, ietwat verwarrend, as sinonien is Ibn Sina self is die quiditeit van enige iets anders as God uitsluitend ten opsigte van die bestaan van die saak: die saak se bestaan en daarom quiditeit (en andersom) word dus regstreeks aan God ontleen. nec reales in metaphysica [onkundige terministe, nierealisties in metafisika].

Dat daar inderdaad in die tweede helfte van die 14de eeu voortdurende strydgesprekke tussen nominaliste en Skotiste was, is nie te betwyfel nie. Die gesprekke was inderdaad soms ook buitengewoon esoteries: 'n weeklange simposium oor Skotus se gebruik van leestekens byvoorbeeld, was niks vreemd nie (Pascoe 1973:89). Maar dit was alles behalwe 'kekkel': Op die spel was die legitimiteit van nadenke oor die attribute van God. Dit het gegaan oor twee soorte verwonderinge aan God, 'n ouer en 'n moderner verwondering (famosiores et moderniores modi imaginandi). Die ouer, Skotiaanse manier was om te argumenteer dat die attribute of 'perfeksies' van God werklik onderskeibaar is (attributa sive perfectiones distinguuntur instrinsece ex natura rei), terwyl die moderner, nominalistiese manier was om te argumenteer dat die attribute van God op geen wyse geskei of selfs onderskei kan word nie (nulle perfectiones sunt in divina essentia ex natura rei ab invicem formaliter vel realiter differentes). Wesenlik het die twee groepe, in die laat-14de eeu inderdaad reeds eerder akademiese groepe as nog skole in die skolastiese sin, twee verskillende metodologiese premisses gehad: die Skotiste was naamlik gerig op metafisiese ondersoek, en die nominaliste op terministieslogiese ondersoek (Luscombe 2004:172). Tot vandag toe, in terme van die analitiese en kontinentale (onder)skeiding in die filosofie, is dit nog so.

Gersonius se polemiese karikatuur van die twee groepe het egter nie die intens akademiese kwaliteit van die SkotistiesOckhamistiese divisie eerbiedig nie. Hy is die laaste van die laat-14de eeuse teologiese leermeesters, wat nog 'n teruggaan na ' $\mathrm{n}$ tyd voor hierdie divisie kontempleer. Tog is Gersonius se angstige interesse juis vir 'n respektabele teologie (Pascoe 1973:179) en dus nie bloot die neurotiese uitvaart van 'n Middeleeuse universiteitsburokraat nie. Sy nostalgie en verantwoorde konserwatisme blyk byvoorbeeld duidelik uit sy lang brief, getitel 'Jucundum', waarin hy onverbloemd terug probeer gryp na die hoog-skolastiek, die tyd voor die divisie, deur herbesoek te bring aan Bonaventura, Thomas Aquinas en Hendrik van Gent, juis deur hulle as teologies-filosofiese ideaaltipes voor te hou (vergelyk Pascoe 1973:182). Hy dring daarop aan dat teologie lojaal bly teenoor haar patristiese en skolastiese tradisies, sowel as aan Aristoteles se logika.

Hy blameer die Skotiste vir hulle Platoniese inklinasies en neiging tot Augustiniaanse eksemplarisme, in die Skotiaanse gelykstelling van Goddelike idees met universeles deur die toepassing van die 'formele onderskeid'. Die Skotiste, na Gersonius se mening, is Platoniste wat die ewige quiditeite buite die intellek van God stel, as sodanig ongeskep deur God en inderdaad nie skepbaar of vernietigbaar deur God nie. Daarby verklaar Gersonius oorlog teen Thomas Bradwardine en die ander Oxford Rekenaars se volgelinge, vir die aanvanklike invoering van logika en metafisika in die teologie, die latere invoering van wiskunde in die teologie, 
die uiteindelike skeiding van teologie en filosofie en ten laaste, die verselfstandiging van die natuurwetenskappe.

In kort: Gersonius kasty die infertilis varietas van die postskolastiek van sy tyd, juis op grond van hierdie eksponente se skolastiese voorgeskiedenisse. Gersonius se diskoers skep uiteindelik egter die indruk van 'n selfflagellant: Met sy ironisering, polemisering en viktimisering van die postskolastiek, folter Gersonius wesenlik sy eie post-skolastiese posisie in die eerste twee dekades van die 15de eeu. Nietemin is Gersonius se posisie bona fide geldig: lojaliteit teenoor die tradisie en intrinsieke outoriteit (kerk, eksegese en pous) en die subordinering van filosofie aan die oorhoofse oordeel van die geloof en vertroue in die patristiese en skolastiese erfenisse. Post-skolastiek, inderdaad getraumatiseer deur die ontwikkelinge vanaf Marsilius van Padua tot by Blasius van Parma, het ook hierdie reaksionêre standpunt nodig gehad nie noodwendig om die post-skolastiek diskursief uit te kon daag nie, maar juis om aan te kon toon dat die reaksie op daardie stadium van die sekulariserende, materialiserende en proto-humaniserende impetus nie gestop sou kon word nie, selfs nie deur die kanselier van die Universiteit van Parys, met al sy jeugdig-energieke, oratoriese en publiserende begaafdheid nie.

\section{Gersonius versus Ruusbroec (postuum), 1399}

So aangrypend as wat sy geleefde lewe was, is een van die mees fassinerende aspekte van Ruusbroec se lewe na die oordeel van hierdie leser, juis dít wat binne twee dekades na sy afsterwe te Groenendaal gevolg het: Die jong en voortvarende Gersonius besluit in 1399 naamlik op grond van sy (rudimentêre) lesing van Die geestelike brulocht, waarin Ruusbroec 'n geestelike universum postuleer, waarin die menslike gees tot Goddelike hoogtes gevoer word en waarin hy betoog vir die reeds aardse vervolmaking en vereniging van die menslike siel met God as die diepste grondteken vir alle sin aan ' $n$ andersins absurde menslike bestaan, te verketter (Ampe 1975:45-261; Burger 1993:43-45; Combes 1945-1972; Warnar 2007:1 [vn.1]).

Soveel verering as wat daar vir Ruusbroec by Groenendaal was, soveel en meer argwaan was daar onder 'n venynige groep skolastici te bespeur ten opsigte van wat as 'ernstige mistastings' in Die geestelike brulocht voorgehou is (Warnar 2007:1). Gersonius was daarvan oortuig dat Ruusbroec die fundamentele skolastiese wet van ' $n$ absolute differensie tussen Skepper en skepsel, verontagsaam en effektief verwerp het. In nog 'n ironiese toegewing verklaar Gersonius dat Die geestelike brulocht 'heeltemal te veel teologiese erudisie reflekteer' as wat van 'n werk wat sogenaamd 'Goddelik geïnspireerd' sou wees, 'verwag kan word' (Warnar 2007:2). Gersonius stel in 1399 gevolglik voor dat Die geestelike brulocht amptelik tot kettery veroordeel word.

Hierdie potensiële veroordeling het in Groenendaal tot uitermate ontsteltenis aanleiding gegee: Op hierdie stadium was reeds vordering gemaak met die Latynse vertaling van Ruusbroec se tekste vanuit die Middelnederlandse vernakulêr, toegerus met behoorlike inleidingshoofstukke deur sy redakteurs, waarin die kwaliteit van die teologiese argumentvoering in die 11 werke benadruk word, eerder as die inderdaad 'Goddelik geïnspireerde' kwaliteite daarvan (Warnar 2007:2). Die leermeester by Groenendaal, Jan van Schoonhoven, wat as jong monnik nog ' $n$ aantal jare in Ruusbroec se geselskap en teenwoordigheid kon deurbring voor Ruusbroec se afsterwe in 1381, het ook reeds begin met 'n konstruktiewe en omvangryke biografie oor die lewe en werk van sy prior. Gersonius se fulminering teen Die geestelike brulocht het al hierdie werk egter terug in die skadus van die hoog-skolastiek geplaas.

Sy uitgediende skolastieke lojalisme ten spyt, was Gersonius ongetwyfeld ' $n$ gerespekteerde teoloog met ' $n$ besonderse statuur: 'n Mens vorder nie tot kanselierskap van 'n eminente instansie soos die Universiteit van Parys op die ouderdom van 32, sonder bewese vermoëns nie. Sy tirade teen 'n afgestorwene was ook nie sonder meer misplaasd nie: die skolastiek bestaan immers oorwegend uit polemieke met die dooies - Johannes Duns Skotus is effektief eers gepolemiseer na sy voortydige dood in 1308, om maar een voorbeeld te noem. Dit was egter juis die styl van Gersonius se vendetta teen Ruusbroec (deur herhaaldelik en uiters pejoratief onder meer na Ruusbroec as 'waansinnig' en na Die geestelike brulocht as insania te verwys; Warnar 2007:2, 3, [vn.3]; sien ook Elliot 2002:30), wat die kloosterlinge by Groenendaal in beweging en tot daadwerklike verset teen Gersonius gebring het.

Van Schoonhoven self, wie se Ruusbroec-biografie of vita (weliswaar in haliografiese aanbod) in vergetelheid weggeval en waarskynlik selfs die eerste helfte van die 14de eeu nie oorleef het nie, het aangebied om in sy hoedanigheid as ' $n$ baccalareus in teologie by Parys, 'n skolastiese argument téén Gersonius se veroordeling van Ruusbroec te formuleer (Ampe 1975:221 ev.) Gersonius wys hierdie teenargument van Van Schoonhoven egter summier af, met die byvoeging dat Ruusbroec sélf hom in sy latere werke reguit van sy vroeëre werk gedistansieer het.

Gersonius was ook woedend daaroor dat Van Schoonhoven onwrikbaar juis die akademiese integriteit van Die geestelike brulocht onderskryf het en nie voorspelbaar in Gersonius se lokval getrap het, deur die kwessie van die 'Goddelike inspirasie' van die teks voorop te stel in sy teenargument nie. Nietemin voer Van Schoonhoven onderbeklemtoond en subtiel aan - soos dit 'n Ruusbroec-geslypte mistikus betaam - dat die teks wel 'Goddelik geïnspireerd' is in die sin dat die soort wysheidsleer wat Ruusbroec aanbied, eenvoudig nie deur studie verinnerlik kan word nie. Ruusbroec se 'kennis' is 'n superieure soort kennis, wat wetenskaplike (en juis die grense van skolastiese) kennis transendeer.

Gersonius aanvaar eg-skolasties natuurlik die openbaring as kenteoretiese bron vir die spreke oor God, maar dring aan op 
skolastiese teologie se finale en arbitrerende vermoë in alle sake wat syns insiens op 'idiosinkratiese spekulasies' berus. Dit is juis die basis van sy kritiek teen Die geestelike brulocht en inderdaad die basis van sy veroordeling van Ruusbroec as ketter: daar is nie genoeg teologie nie en geen sterk, weerstandige teologiese raamwerk van waaruit Ruusbroec se mistiek aangebied word nie. Hoewel Ruusbroec se teoretiese uitgangspunte rondom 'n apologeties-kategetiese-, dogmatieseen pastoraal-biografiese motief, die kerklike leer uitdruklik nie teengaan nie, is die leser volgens Gersonius uiteindelik nie op die kategetiese elemente, dogmatiese strekkinge en pastorale leidsmotiewe in Die geestelike brulocht aangewese om die waarheidswaarde daarvan te peil nie, maar op ' $n$ subjektiewe interpretasie van 'n mistiek wat sélf reeds skerp subjektivisties is. Dít is waarteen Gersonius hom rig.

Die 'teologiese armoede' teenoor 'n spiritueel subjektiewe ooraanbod' was egter nie die enigste oorweging in Gersonius se tirade teen Die geestelike brulocht nie. Gersonius was reeds berug, soos hierbo aangedui, vir sy voorliefde vir 'n polemisering van alles en almal wat anders dink en leef as hy, synde Latyns-Westerse dogmatikus en poortwagter van die skolastiese metode in die laat-14de eeu. Dat hy dus hoegenaamd moet reageer teen ' $n$ teks wat in ' $n$ 'lae taal' - Middelnederlands - vanuit boonop 'n 'lae land' Vlaandere-Brabant - aangebied word, vind Gersonius verleentheidswekkend. Wanneer daarby gevoeg word die waardering vir aspekte van die ouer begynse tradisie in Ruusbroec se tekste - en die begyne was een van Gersonius se voorkeurteikens - asook dat Gersonius 'n kritiese metgesel gevind het in die teoloog Hendrik van Langenstein se kritiek van Die geestelike brulocht reeds 'n jaar voor Ruusbroec se afsterwe, was Ruusbroec as ' $n$ individu en Die geestelike brulocht as ' $n$ teks vir Gersonius net een te veel. Ruusbroec is 'n ketter en Die geestelike brulocht is kettery (Warnar 2007:3).

Die post-skolastiese element in Ruusbroec se mistiek kry egter beslag in Van Schoonhoven se finale verweer, wat niks minder as 'n uitklophou was nie. Van Schoonhoven wys juis met tegniese jukstaposisies in die hoogs stilistiese Latynse vertalings van die oorspronklike Middelnederlandse tekste (en Gersonius kon net die Latynse vertalings lees), dat Gersonius se interpretasies van Ruusbroec growwe wanvoorstellings is van wat Ruusbroec in terme van outeursintensie vanuit ' $n$ subtiele begrippevoorkeur probeer aanbied het - 'n voorkeur wat, sou ons vandag kon sê, slegs hermeneuties ontdek sou kon word, wanneer die leser sy of haar eie vooroordele en onvermoë eers verreken, voordat beslissende uitsprake oor 'n teks gemaak word.

Wanneer daarby gevoeg word dat Ruusbroec se aanvanklike Latynse vertaler Willem Jordaens ' $n$ voorliefde gehad het vir semantiese- of betekenisvertalings en nie woordelikse, sintaktiese vertalings nie - Van Schoonhoven verwys onder meer na Jordaens se 'blomryke Latyn' - is dit vir die Groenendalers duidelik dat Gersonius nie verstaan wat hy lees wanneer hy Ruusbroec lees nie. Op die uitkloptelling van tien voeg Schoonhoven by dat Gersonius se gewaande meerderwaardigheid eintlik in 'n grondige minderwaardigheid vestig. Gersonius kon homself nie so ver kry om dit wat hy wel vanuit die Latyns-vertaalde Ruusbroec verstaan het, te begryp as die werk van 'n nie-skolastiese en - binne sy skolastiese definisie van geadministreerde geleerdheid - inderdaad ongeleerde skrywer wat so uitermate bevoeg skryf oor die buitengewoon komplekse temas wat in Die geestelike brulocht hanteer word nie.

Die postuum konfrontasie van Gersonius met Ruusbroec word in die verwysde literatuur normaalweg neutraal hanteer. Dit het daarvolgens beide denkers se erfenisse onherroeplik beskadig - en daar was geen wenners in Gersonius se versus-inisiatief nie. Die skrywer is nie bewus van enige interpretasies tot op datum wat die swaarwig juis na Ruusbroec en die Groenendalers toe laat leun nie. In hierdie interpretasie word dit wel met daardie swaarwig en selfs as ' $n$ triomf vir Ruusbroec aangebied. Dink daaraan: 'n klein groepie 'Augustiniaanse monnike' (wat 'Augustiniaans' was net omdat hulle deur kerklik-geïniseerde wetgewing verplig was om tot ' $n$ bestaande Ordereël te konformeer), waarvan die akademies bes-gekwalifiseerde ' $n$ baccalaureus in teologie was, slaag daarin om die vendetta van 'n jong, energieke en lojalistiese skolastikus vanuit die hoogste echelons van die Middeleeuse akademiese lewe, af te weer.

Inderdaad was hierdie 'n geveg waar daar nie wenners was of kon wees nie. Die punt is egter dat Gersonius effektief teengegaan is. Hierdie insident het hom óók verwond: Die feit dat hy self later in sy akademiese loopbaan al sterker in 'n mistieke teologie begin opgaan het (sien Combes 1963; Fisher 2006; Vial 2006), mag heel moontlik die resultaat wees van hierdie een konfrontasie, wat hy gewis nie gewen het nie. Dit val die skrywer in hierdie genuanseerde $\sin$ op as wel 'n 'triomf', nie soseer vir Ruusbroec en die Groenendalers nie, maar vir die sin vir progressie wat in die post-skolastiek aanwesig was. Post-skolastiek, as die transformasie en selektiewe afskeid van hoog-skolastiek, tree hier na vore as ten diepste ook 'hermeneuties', soos wat dit vanaf die 19de eeu by Dilthey, Schleiermacher, Heidegger en Gadamer bekend sou staan. "Post-skolastiese mistiek', met Ruusbroec en die Groenendalers as geleier, bepleit hermeneutiesimplisiet vir 'n verdraagsaamheid by lesers, waar (mistieke) onsekerheid eerder as (skolastiese) sekerheid, interpretatiewe beskeidenheid en selfonderbreking sleutels word om tekste te lees en te internaliseer. Gersonius kon ewe wel toegegee het: ek verstaan dit nie. Maar omdat daar geen sin vir selfonderbreking in die skolastiek was nie - alle werklike sekerhede was immers skolastiese sekerhede, getoets aan die skolastiese metode - was dit nie vir hom moontlik om daardie toegewing te maak nie.

Hierdie artikel argumenteer dus vanuit die raamwerk van 'n 'post-skolastiek' dat ook hier by Ruusbroec, soos by Padua, Bradwardine, Wyclif, Blasius van Parma, Biel en talle ander post-1349, pre-1464 denkers,die hoog-skolastiek in hierdie periode met 'n selektiewe afskeid van elemente in die hoogskolastiek, getransformeer word. Tot hierdie repertoire lewer Ruusbroec en die Groenendalers ' $n$ daadwerklik bydrae: 
kontra-skolastiese beskeidenheid, selfonderbreking en die gewilligheid om eie beperkinge toe te gee, sodat die skrywer van welke aweregse teks ook al, in waarheidsoeke ontmoet word - eerder as afgewys word, of soos by die skolasties-lojale Gersonius, veroordeel, gemarginaliseer en geostraseer word.

Gersonius se voorneme om Ruusbroec tot ketter en Die geestelike brulocht tot kettery veroordeel te kry, het gefaal. Natuurlik is Ruusbroec se reputasie skade gedoen, maar die ewigdurende oneer om as 'ketter' verklaar te word, is afgeweer. Wat fataal sou wees, is verminder tot 'n verwonding. Dat selfs diep wonde weldra genees, word daarin betuig dat ' $n$ briljante institusionele biograaf, Henricus Pomerius, in 1420 so aangegryp is deur Ruusbroec en die Groenendalers se verhaal, dat hy dit gesaghebbend geboekstaaf het in 'n oorsigwerk oor die Augustiniaanse klooster te Groenendaal, getitel De origine monasterii Viridisvallis (Warnar 2007:3 [vn. 3 en 4]).

By die aanvang van sy projek kondig Pomerius (in Warnar 2007:3) in die Latynse teks aan dat die eerste volume van hierdie magistrale werk gewy sal word aan 'Die geseënde lewe en heilige sedes van die altyd-toegewyde vader, broeder Jan van Ruusbroec, die eerste hoofmonnik van Groenendaal.' Uit juis 'n diepe hermeneutiese agting vir Jan van Ruusbroec, en die ander Groenendalers, sou hierdie vertaling in Afrikaans vanuit die Latynse teks na die skone Middelnederlands terugvertaal moes word:

Dat salige leven ende heilige seden des alre devoets vaders, brueder Johannes van Ruysbroec, des iersten priors van Gruenendael.

Ut enim monachorum opera legerem, necesse erat me ipsum monachum fieri.

Geskryf by die Ruusbroec Instituut, Universiteit van Antwerpen, Mei 2019.

\section{Erkenning \\ Mededingende belange}

Die outeur verklaar dat hy geen finansiële of persoonlike verbintenis het met enige party wat hom nadelig kon beïnvloed in die skryf van hierdie artikel nie.

\section{Outeursbydrae}

J.B. was die enigste outeur betrokke by die skryf van die artikel.

\section{Etiese oorwegings}

Hierdie artikel volg alle etiese standaarde vir navorsing sonder direkte kontak met mens of dier.

\section{Befondsing}

Befondsing is verskaf deur die Departement Filosofie, Fakulteit Geesteswetenskappe, Universiteit van die Vrystaat.

\section{Data beskikbaarheidsverklaring}

Data-deling is nie van toepassing op hierdie artikel nie, aangesien geen nuwe data in hierdie studie geskep of ontleed is nie.

\section{Vrywaring}

Die sienings en menings wat in hierdie artikel uitgedruk word, is dié van die outeur en weerspieël nie noodwendig die amptelike beleid of posisie van enige geaffilieerde agentskap van die outeur nie.

\section{Literatuurverwysings}

Ampe, A., 1975, Ruusbroec. Traditie en werklijkheid, Ruusbroec-Genootschap, Antwerp.

Arblaster, J. \& Faesen, R., 2014, 'John of Ruusbroec's life and works', in J. Arblaster \& R. Faesen (eds.), A companion to John of Ruusbroec, pp. 47-80, Brill, Leiden.

Arblaster, J. \& Faesen, R. (eds.), 2014, A companion to John of Ruusbroec, Brill, Leiden.

Arblaster, J. \& Faesen, R. (eds.), 2017, Mystical anthropology. Authors from the Low Countries, Routledge, London.

Beukes, J., 2012, 'Vanaf Ockham na Kusa: Die ensiklopediese aanspraak van ' post-skolastiek in Middeleeuse filosofie', HTS Teologiese Studies/Theological Studies 68(1), Art. \#2381, 2352-2361. https://doi.org/10.4102/hts.v68i1.1134

Beukes, J., 2019a, 'Hildegard von Bingen as 'n 12de-eeuse filosoof-teoloog', Litnet Akademies 16(1), 64-102.

Beukes, J., 2019b, 'Maak die wêreld nie tot bespotting nie: 'n Herwaardering van die filosofiese aspekte in Mechtild von Magdeburg se Das fließende Licht der Gottheit (1250)', Verbum et Ecclesia, Art. \#1965, 40(1), 1-8. https://doi.org/10.4102/ $(1250)^{\prime}$, Verbum
ve.v40i1.1965

Beukes, J., 2020a, Middeleeuse Filosofie, Akademia, Pretoria (In publikasie).

Beukes, J., 2020b, 'Die eliminering van die siel in die filosofiese mistiek van die begyn Marguerite Porete (1250-1310)', Litnet Akademies 17 (In publikasie).

Beukes, J., 2020c," $n$ Nijmegenaar aan die Universiteite van Parys en Heidelberg in die latere Middeleeue: die lewe en werk van Marsilius van Inghen (ca.1340-1396)', Verbum et Ecclesia 41, Art. \#2038 (In publikasie).

Bos, E.P. \& Warnar, G. (eds.), 1993, Een claer verlicht man. Over het leven en werk van Jan van Ruusbroec (1293-1381), Verloren, Hilversum.

Burger, C., 1993, 'De mysticus Ruusbroec en zijn kerk', in E.P. Bos \& G. Warnar (eds.) Een claer verlicht man. Over het leven en werk van Jan van Ruusbroec (1293-1381), pp. 31-45, Verloren, Hilversum.

Bynum, C.W., 1984, Jesus as Mother. Studies in the spirituality of the high Middle Ages, University of California Press, Los Angeles, CA.

Colledge, E. \& Marler, J.C., 1984, 'Poverty of the will: Ruusbroec, Eckhart and The Mirror of Simple Souls', in P. Mommaers \& N. De Paepe (eds.), Jan van Ruusbroec. The sources, content and sequels of his mysticism, Medieaevalia Lovaniensia I/XII, pp. 14-47, Louvain University Press, Louvain.

Colnect, n.d. Jan van Ruusbroec, viewed n.d., from https://colnect.com/en/stamps/ stamp/67114-Jan_van_Ruusbroec-Belgium.

Combes, A., 1945-1972, Essai sur la critique de Ruysbroeck par Gerson, vol. I-III, Vrin, Paris.

Combes, A., 1963, La théologie mystique de Gerson. Profil de son évolution, Desclee et Socii, Rome.

Cornet, I., 2017, 'The inner ascent to God and the innermost of the human person in the Arnhem Mystical Sermons', in J. Arblaster \& R. Faesen (eds.), Mystical anthropology. Authors from the low countries, pp. 137-151, Routledge, London.

De Baere, G., 1984, 'Die neue Ruusbroec-edition und ihr erster Band, das Boecsken der verclaringhe', in P. Mommaers \& N. De Paepe (eds.), Jan van Ruusbroec. The sources, content and sequels of his mysticism, Medieaevalia Lovaniensia I/XII, pp. 176-186, Louvain University Press, Louvain.

De Baere, G., 2014, 'Ruusbroec in edition: Manuscript and print', in J. Arblaster \& R. Faesen (eds.), A companion to John of Ruusbroec, pp. 81-99, Brill, Leiden.

Eckenstein, L., 2010, Woman under monasticism. Chapters on Saint-Lore and convent life between A.D. 500 and A.D. 1500, Theophania, Calgary.

Elliot, D., 2002, 'Seeing double: John Gerson, the discernment of spirits, and Joan of Arc', American Historical Review 107, 26-54. https://doi.org/10.1086/532095

Erb, P.C., 1984, 'The use of Ruusbroec among German Protestants', in P. Mommaers \& N. De Paepe (eds.), Jan van Ruusbroec. The sources, content and sequels of his mysticism, pp. 153-175, Louvain University Press, Louvain. (Medieaevalia Lovaniensia I/XII).

Faesen, R., 2017, 'Poor in ourselves and rich in God: Indwelling and non-identity of being (wesen) and suprabeing (overwesen) in John of Ruusbroec', in J. Arblaste (ed. \& transl.) \& R. Faesen (ed.), Mystical anthropology. Authors from the Low Countries, pp. 59-72, Routledge, London.

Figgis, J.N., 1999, Political thought from Gerson to Grotius, 1414-1625: Seven studies, Batoche Books, Kitchener, ON. 
Fisher, J., 2006, 'Gerson's mystical theology: A new profile of its evolution', in B.P. McGuire (ed.), A companion to Jean Gerson, pp. 205-248, Brill, Leiden.

Gersonius, J., 1987, Opera Omnia, vol. I-V, Georg Olms Verlag, Hildesheim.

Gersonius, J., 1998, Early works (1401-1408), in B.P. McGuire (intr., ed. \& transl.), Jean Gerson: Early works (1401-1408), pp. 129-398, Paulist Press, New York.

Gracia, J.J.E. \& Noone, T.B. (eds.), 2006, A companion to philosophy in the Middle Ages, Blackwell, Oxford.

Hobbins, D.B., 2003, 'The schoolman as public intellectual. Jean Gerson and the late Medieval tract', The American Historical Review 108, 1308-1337. https://doi. org/10.1086/529968

Hobbins, D.B., 2006, 'Gerson on lay devotion', in B.P. McGuire (ed.), A companion to Jean Gerson, pp. 41-78, Brill, Leiden.

Hobbins, D.B., 2009, Authorship and publicity before print. Jean Gerson and the transformation of late Medieval learning, University of Pennsylvania Press, Philadelphia, PA.

Krüger, J.S. (intr. \&transI.), 2003, Duister stilte en wilde woestyn. Die mistiek van Jan van Ruusbroec (1293-1381): oor 'Die geestelike brulocht', Aurora Press, Pretoria.

Lagerlund, H. (ed.), 2011, Encyclopedia of Medieval philosophy. Philosophy between 500 and 1500, Springer, London.

Lewis, G.J., 1989, Bibliographie zur deutschen Frauenmystik des Mittelalters, Erich Schmidt Verlag, Berlin.

Luscombe, D.E., 2004, Medieval thought, Oxford University Press, Oxford.

Mazour-Matusevich, Y., 2006, 'Gerson's legacy', in B.P. McGuire (ed.), A companion to Jean Gerson, Brill, Leiden, pp. 357-400.

McDonnell, E.W., 1954, The beguines and beghards in Medieval culture, Rutgers University Press, New Brunswick, NJ.

McGinn, B., 2014, 'Essential themes in Ruusbroec's mysticism', in J. Arblaster \& R. Faesen (eds.), A companion to John of Ruusbroec, pp. 130-178, Brill, Leiden.

McGuire, B.P. (ed.), 2006a, A companion to Jean Gerson, Brill, Leiden.

McGuire, B.P., 2006, 'In search of Jean Gerson: Chronology of his life and works', in B.P. McGuire (ed.), A companion to Jean Gerson, pp. 1-40, Brill, Leiden.

McGuire, B.P., 2011, 'John Gerson', in H. Lagerlund (ed.), Encyclopedia of Medieval philosophy. Philosophy between 500 and 1500, pp. 621-623, Springer, London.

Mommaers, P., 1981, 'Introduction', in G. Baere (ed.), P. Mommaers (intr.) \& H. Rolfson (transl.), Opera Omnia 1. Boecsken der verclaringhe, edited by the Ruusbroec Genootschap, pp. 17-41, 55-80, University of Antwerp, Brill, Leiden.

Mommaers, P., 2009, Jan van Ruusbroec: Mystical union with God, Peeters, Louvain.

Mommaers, P. \& De Paepe, N. (eds.), 1984, Jan van Ruusbroec. The sources, content and sequels of his mysticism, Medieaevalia Lovaniensia I/XII, Louvain University Press, Louvain. (Medieaevalia Lovaniensia I/XII).

Noë, H., 2014, 'Ruusbroec the author', in J. Arblaster \& R. Faesen (eds.), A companion to John of Ruusbroec, pp. 100-129, Brill, Leiden.

Oakley, F., 2006, 'Gerson as conciliarist', in B.P. McGuire (ed.), A companion to Jean Gerson, pp. 179-204, Brill, Leiden.

Ouy, G., 2006, 'Gerson the humanist: Fifty years of serendipity', in B.P. McGuire (ed.) A companion to Jean Gerson, pp. 79-132, Brill, Leiden.

Palazzo, A., 2011, 'Denys the Carthusian', in H. Lagerlund (ed.), Encyclopedia of Medieval philosophy. Philosophy between 500 and 1500, pp. 258-260, Springer, Medieval
London.

Pascoe, L.B., 1973, Jean Gerson: Principles of Church Reform, Brill, Leiden.

Pelletier, J.E., 2013, William Ockham on metaphysics. The science of being and God, Brill, Leiden.

Pelletier, J.E., 2017, 'Is there a metaphysical approach to the transcendentals in Ockham? The case of the Good', in J.E. Pelletier \& M. Roques (eds.), The language of thought in late Medieval philosophy. Essays in honor of Claude Panaccio, pp. 111-124, Springer, London.
Pelletier, J.E. \& Roques, M. (eds.), 2017, The language of thought in late Medieval philosophy. Essays in honor of Claude Panaccio, Springer, London.

Petry, R.C., 2006, 'Jan van Ruysbroeck (1293-1381): Introduction', in R.C. Petry (intr., ed. \& transl.), Late Medieval mysticism, pp. 285-291, Westminster John Knox Press, Lousville, KY

Rolfson, H., 1984, 'Ruusbroec in American English', in P. Mommaers \& N. De Paepe (eds.), Jan van Ruusbroec. The sources, content and sequels of his mysticism Medieaevalia Lovaniensia I/XII, pp. 187-195, Louvain University Press, Louvain. (Medieaevalia Lovaniensia I/XII).

Ruusbroec, J.V., 1981a, Opera Omnia, 1. Boecsken der verclaringhe, in G. de Baere (ed.), P. Mommaers (intr.) \& H. Rolfson (transl.), edited by the Ruusbroec Genootschap, Universityof Antwerp, Brill, Leiden. (See Ons Geestelijk Erf 20/1 1981 and Corpus Christianorum Continutatio Mediaevalis 1011989).

Ruusbroec, J.V., 1981b, Opera Omnia, 2. Vanden seven sloten, G. de Baere (ed.) \& H. Rolfson (transl.), Brill, Leiden. (See Ons Geestelijk Erf 20/2 1981 \& Corpus Christianorum Continutatio Mediaevalis 1021989).

Ruusbroec, J.V., 1988, Opera Omnia, 3. Die geestelike brulocht, J. Alaerts, (ed.), L. Surius (Latin transl. 1552), H. Rolfson (transl.), Brepols, Turnhout. (See Ons Geestelijk Erf 20/3 \& Corpus Christianorum Continutatio Mediaevalis 103).

Ruusbroec, J.V., 2000, Opera Omnia, 7-7A. Vanden XII beghinen. Prolegomena, M.M. Kors (ed.), L. Surius (Latin transl. 1552), H. Rolfson (transl.), Brepols, Turnhout. (See Ons Geestelijk Erf 20/7-7A \& Corpus Christianorum Continutatio Mediaevalis 107-107A).

Ruusbroec, J.V., 2001, Opera Omnia, 8. Een spieghel der eeuwigher salicheit, G. De Baere (ed.), P. Mommaers (intr.), L. Surius (Latin transl. 1552), A. Lefevere (transl.), Brepols, Turnhout. (See Ons Geestelijk Erf 20/8 \& Corpus Christianorum Continutatio Mediaevalis 108)

Ruusbroec, J.V., 2002, Opera Omnia, 4. Dat rijcke der ghelieven, J. Alaerts (ed.), L. Surius (Latin transl. 1552), H. Rolfson (transl.), Brepols, Turnhout. (See Ons Geestelijk Erf 20/4 \& Corpus Christianorum Continutatio Mediaevalis 104).

Ruusbroec, J.V., 2003, Opera Omnia, 9. Van seven trappen, R. Faesen (intr. \& ed.), L. Surius (Latin transl. 1552), H. Rolfson (transl.), Brepols, Turnhout. (See Ons Geestelijk Erf 20/9 \& Corpus Christianorum Continutatio Mediaevalis 109).

Ruusbroec, J.V., 2006, Opera Omnia, 5-6. Van den geesteliken tabernakel, vol. I \& II, T. Mertens (ed.), L. Surius (Latin transl. 1552), H. Rolfson (transl.), Brepols, Turnhout. (See Ons Geestelijk Erf 20/5-6 \& Corpus Christianorum Continutatio Mediaevalis 105-106).

Schepers, K., 2014, 'Ruusbroec in Latin: Impulses and impediments', in J. Arblaster \& R. Faesen (eds.), A companion to John of Ruusbroec, pp. 237-285, Brill, Leiden.

Schepers, K., 2017, 'Multilayeredness of the highest faculties in the Arnhem Mystical Sermons', in J. Arblaster \& R. Faesen (eds.), Mystical anthropology. Authors from the Low Countries, pp. 152-166, Routledge, London.

Schweitzer, F-J., 1984, “"Caritatem habe, et fac quod vis!" - Die "Freien Geister” in de Darstellung Jans van Ruusbroec und in Selbstzeugnissen', in P. Mommaers \& N. de Paepe (eds.), Jan van Ruusbroec. The sources, content and sequels of his mysticism, pp. 48-67, Louvain University Press, Louvain. (Medieaevalia Lovaniensia I/XII).

South, J.B., 2006, 'John Gerson', in J.J.E. Gracia \& T.B. Noone (eds.), A companion to philosophy in the Middle Ages, pp. 370-371, Blackwell, Oxford.

Vekeman, H.W.J., 1984, 'Vriendschap in de Middelnederlandse mystiek. De plaats van Ruusbroec', in P. Mommaers \& N. de Paepe (eds.), Jan van Ruusbroec. The sources, Ruusbroec', in P. Mommaers \& N. de Paepe (eds.), Jan van Ruusbroec. The sources,
content and sequels of his mysticism, pp. 124-141, Louvain University Press, content and sequels of his mysticism, pp.
Louvain. (Medieaevalia Lovaniensia I/XII).

Verdeyen, P., 1984, 'Essai de biographie critique', in P. Mommaers \& N. de Paepe (eds.), Jan van Ruusbroec. The sources, content and sequels of his mysticism, pp. (eds.), Jan van Ruusbroec. The sources, content and sequels of his mysticism,
$1-13$, Louvain University Press, Louvain. (Medieaevalia Lovaniensia I/XII).

Vial, M, 2006, Jean Gerson.Théoricien de la théologie mystique, Vrin, Paris.

Warnar, G., 2007, Ruusbroec. Literature and mysticism in the fourteenth century, D. Webb (transl.), Brill, Leiden.

Wiseman, J.A., 1984, 'Minne in Die gheestelike brulocht', in P. Mommaers \& N. de Paepe (eds.), Jan van Ruusbroec. The sources, content and sequels of his mysticism pp. 86-99, Louvain University Press, Louvain. (Medieaevalia Lovaniensia I/XII). 